\title{
CEU Summer University Call for Applications
}

Interdisciplinary summer university course "Urban governance and civic participation in words and stone: Urbanism in Central Europe 1200-160o" at Central European University (CEU), Budapest and Prague, July 11-19, 2022.

"A city (civitas) is a number of men joined by a social bond. It takes its name from the citizens who dwell in it." This is how Isidore of Seville defined the city in the seventh century. As we can glean from this definition, the human element is all-encompassing, and the physical space is of secondary importance. Indeed, cities are characterized by their populations, which are larger, denser and more complex than that of the surrounding countryside. They have been established to fulfill central functions in the production, exchange and consumption of commodities and serve as administrative and religious centers for a given district, region or realm. In order to realize these functions efficiently, cities were granted or gradually acquired a certain degree of autonomy and developed their own governing bodies and institutions, with varying degrees of participation by inhabitants of different social and legal standing. The system of governance necessitated the use of administrative literacy and the appropriate shaping of the physical environment, including its open spaces, buildings and ornaments.

A millennium after Isidore, Rousseau, in a footnote to his Social Contract (1762), complained that people have almost forgotten the real meaning of the word city (cité) in modern times: "They do not know that houses make a town, but citizens a city." How did the notion of civic participation change throughout history, and how were these changes reflected in the foundations of political thought? In what forms of expression did it surface in various written and visual media of the

1 Isidore of Seville, The Etymologies of Isidore of Seville, transl. Stephen A. Barney (Cambridge: Cambridge uP, 2006), 305.

2 Jean-Jacques Rousseau, "The Social Contract," in The Social Contract and Discourses, trans. George Douglas Howard Cole (London: Everyman, 1993), 180-341, n. 192. 
Middle Ages and the Early Modern period? These questions will be the focus of the summer university course. ${ }^{3}$

Medieval cities and towns present an important object of international historical, archaeological, and architectural investigations and studies on political thought. The results of this research have given ample fodder for academic debates on the creation and growth of towns; the role of seigniorial power, civic initiatives, and external forces in these processes; and the role of migration, colonization, and cultural transfer in the spreading of urbanization - to name only a few. Related topics have formed the core of a lecture series, Urban Governance and Civic Participation in Words and Stone, which served to prepare the grounds for the summer university course and was hosted by the CEU Democracy Institute and the Department of Medieval Studies in the Fall Term of 2021. ${ }^{4}$ The summer university course will provide the opportunity to investigate the topic of urban governance in further detail and open up new interdisciplinary avenues of research for interested young scholars from the perspectives of art history, social history, pragmatic literacy, and urban planning.

The summer university courses will be taught by distinguished scholars in the field. Katalin Szende, a prominent urban historian and professor at the Department of Medieval Studies (CEU), will open the floor with an introductory lecture on the concept of the Central European city in time and space. Felicitas Schmieder (University of Hagen) will then take over to discuss the legal background of urban autonomy and free burghers in German cities. One of the key themes of the course is civic participation, which will be covered by Susanne Rau (University of Erfurt), focusing on governments in pre-modern cities, while Ferenc Hörcher (University of Public Service Budapest) will delve deeper into urban republicanism and the political principles of late medieval cities in general. Last but not least, the course will look at the intersections of the administrative and spatial or architectural realms. Zoë Opačić (Birkbeck, University of London) will focus on the secular sphere and the performative functions of town squares,

3 For the latest news and updates, see summeruniversity.ceu.edu.

4 The lecture series was co-organized with the Department of History of Art at Birkbeck, University of London, and the Faculty of Philosophy at the University of Erfurt. The talks of various speakers focused on the origins of civic participation in political thought and explored its forms of expression in written and visual media from late antiquity to the seventeenth century. The lectures were made available online at democracyinstitute.ceu.edu. 
while Béla Zsolt Szakács (CeU, Pázmány Péter Catholic University) will give a lecture on sacred architecture in the urban context.

The interdisciplinary orientation of the course will be reflected in the various types of activities interlacing theory with practice and combining the input of students with that of the faculty. The faculty members will offer thematic lectures to solidify the theoretical foundations, and the participants will be asked to present their research topics and give feedback. In addition, the faculty members will lead different workshops analyzing a specific type of written source (town plans, legal documents) or visual evidence. Finally, under the guidance of József Laszlovszky (CEU), city walks will be organized to provide an immersive experience of the sites and buildings connected to the topics of the lectures and workshops.

One of the course's aims is to foreground the cities and towns of medieval Central Europe (i.e., the medieval kingdoms of Hungary, Poland, and Bohemia) from a comparative perspective. Accordingly, the course will begin with five teaching days in Budapest and conclude with a four-day field trip to Prague, with a stopover in Brno. Besides a few indoor presentations, the main emphasis will be on site visits showcasing some long-term developments in medieval Prague and the post-WWII approach to restoring lost cultural heritage. Through these investigations of the preservation, protection, and value of immaterial and material heritage for modern societies, participants will get a better sense of how the elements of contemporary townscapes reveal their histories and how the knowledge of the past lives of cities contributes to political consciousness and policy-making in the present.

Interested students and young scholars are invited to submit their applications via the website, summeruniversity.ceu.edu, by February $28,2022$.

Anja Božič 